\title{
Sustainable development of the city on the example of Vancouver
}

\author{
Anna Bać \\ Faculty of Architecture, Wrocław Univeristy of Technology, Chair of Housing Design \\ B. Prusa 53/55, 53-317 Wrocław, \\ e-mail: anna.bac@pwr.edu.pl
}

\begin{abstract}
Opinions about the insufficient realization of international strategies taken after the Rio Declaration on Environment and Development in 1992 appeared particularly in the last decade. In spite of adopted legislative acts and the years passing, the global development does not seem positive. The growth of world cities should be accomplished according to the idea of sustainable development, yet it is not easy to be achieved in practice. A deliberate policy and comprehensive action of cities themselves are needed, which will contribute to changes of the current awareness, of beliefs and social behaviour. Popularizing successful examples of sustainable cities seems to be very important. This paper aims to present practical action taken in Vancouver, which caused it to be one of the greenest cities in the world.
\end{abstract}

Keywords: sustainability, Vancouver, urban planning, Greenest City 2020 Action Plan, sustainable communities, green buildings, green solutions.

\section{Introduction and state of the art}

The ecology of contemporary cities includes a much greater notional scope than just concerning the city as an anthropogenic ecosystem with processes of mutual interactions of natural, abiotic and social environment (Zimny 2005). In our times, one should also refer to issues of sustainable development including the achievement of a triple bottom line - the TBL (Ellington 1994). This incorporates three dimensions of performance: social, environmental and financial. The TBL are also commonly called the three Ps: people, planet and profits (Slaper \& Hall 2011). Since the early $60 \mathrm{~s}$ of the $20^{\text {th }}$ century and the publication of the crucial "Silent Spring" by Rachel Carson (1962), which initiated the environmental movement, the approach towards sustainability was enriched by new knowledge and methods. During the Earth Summit in 1992 in Rio de Janeiro, member states of the United Nations accepted the Rio Declaration on Environment and Development, called Agenda 21 (United Nations 1992).
It is a comprehensive plan of action to be taken by organizations of the United Nations system, governments, and major groups in every area in which human impacts on the environment. Agenda 21 has exerted influence on world public opinions, and has also contributed to the new approach to a number of issues, including urban planning. One can particularly observe a lot of action in this subject in the USA and Canada. Probable reasons are the current standards of living and consumption in these countries that need the most significant correction (Suzuki 2007).

At the beginning of 2000, seeking in the Internet for 'evaluation of sustainability' resulted with a few dozen government, corporate, academic, civil society, and personal websites presenting work about sustainability assessment (Gibson 2006). Recently (in October 2013), Google reported over 3.5 million results mentioning the term 'sustainable development of the city in USA and Canada' and thousands of initiatives. Outcome shows the scale and importance of that subject in the contemporary world. There 
a
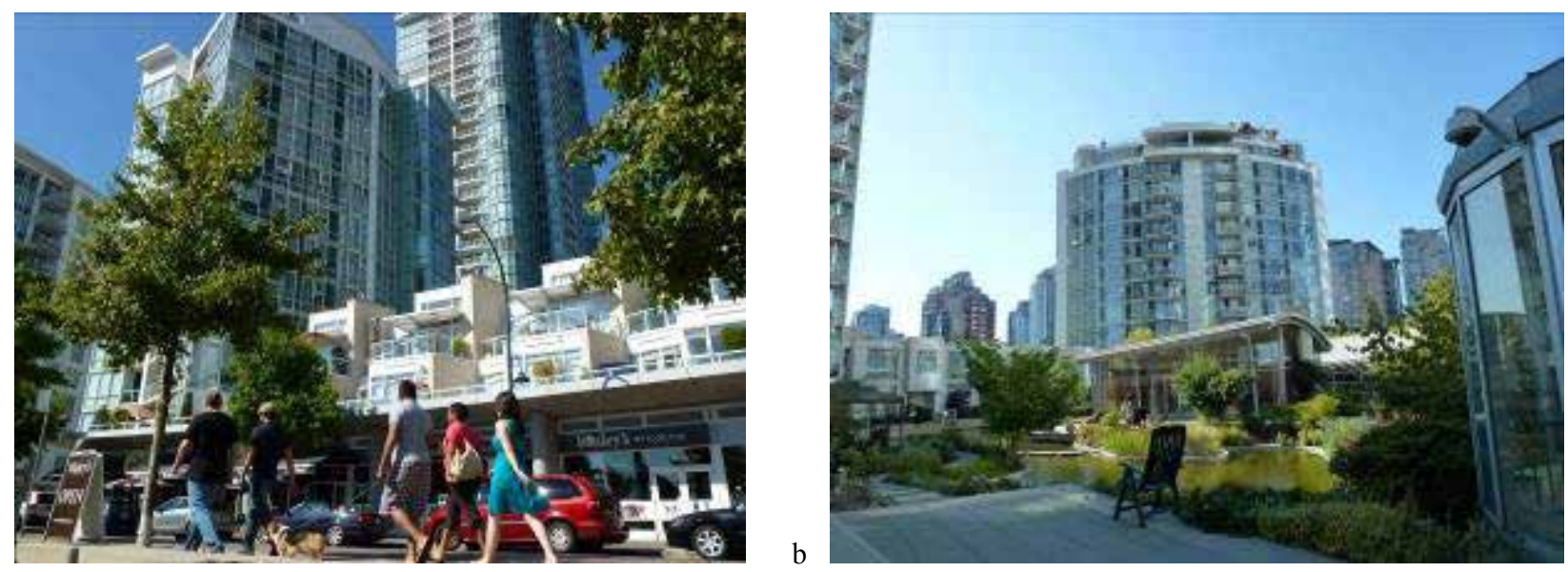

Figure 1. Mixed-use development in Yaletown part of downtown Vancouver: a) services and city villas located in the podium of residential towers, b) community spaces situated over the podium (all the photographs made by the Author)

are single basic elements such as sustainable: 'urban planning', 'city', 'architecture', 'development', 'housing', etc.

In Poland there appear only 221 thousand results to the term 'sustainable development'. These are above all papers on 'sustainability' (among others Zabłocki 2002) and the ecology of cities (among others Wehle-Strzelecka \& Korczyńska 2007; Paszkowski 2011) and sustainable design (among others Baranowski 1998).

In urban planning trends appeared like "Smart Grow", "New Urbanism" or "Green Buildings" (Farr 2008). Researchers and practitioners have created principles to which one should subordinate the contemporary and inevitable development of cities taking into account the needs of future generations (Condon 2010). A so-called mixed-use design is one of the indicators of a balanced town planning, that is units with many functions: residential towers with apartments which hold all essential services in the podium (such as shops and restaurants), and so-called city villas and social spaces intended for residents of towers - over the podium (Fig. 1). This idea is supposed to prevent an uncontrolled urban-sprawl and the formation of housing and office deserts. That purpose is being served i.a. by multicriteria systems of evaluation - they facilitate the creation of sustainability in cities' spaces - Leadership in Energy and Environmental Design - Neighbourhood Development (CAGBC 2012). In many countries one can observe a common fashion for sustainability, ecology and being green. For example, in Canada rankings of sustainable cities have been created.

It has resulted in a slow change of the social awareness what eventually enables to transform cities in the spirit of sustainable development - to take action to satisfy current needs with respect of the needs of future generations (United Nations 1987). Subsequent revisions of reports of the Club of Rome constantly alarm about the emerging need to change the attitudes and behaviour of the mankind (King \& Schneider 1993; Meadows et al. 2004). In spite of many declarations and strategies, it is impossible to state that the world's development has become sustainable.

The mankind needed almost 300 years to officially accept and notice the 'nachhaltigkeit' notion (eng. sustainable) which was used for the first time already in 1713 by Hans Carl von Carlovitz and continued by Georg Ludwig Hartig (1795, after Bader 2008). Consequences of the development, noticed already then, are at present reflected in the uncontrolled production of goods for the growing population and in the impossibility of assimilating this process by natural resources of the Earth (Global Footprint Network 2012).

\section{Planning of town sustainability in practice}

"It's up to everyone to do their part, to rethink, re-evaluate and re-imagine the way Vancouver works and how we lead our lives" - The Greenest City Action Team, Vancouver 2020. A Bright Green Future (2009).

Canadian cities are very good examples of realization of the idea of sustainability. It is possible to recognize sustainability on many levels and this is probably the key to success - to the sustainable development. The law in Canada is the foundation for implementing sustainable development. The Federal Sustainable Development Strategy - FSDS is the legal basis, formed for the first time in 1994 by the Natural Resources Canada - NRCan and renewed every three years (NRCan 2008). This department contains the Energy Sector, in which the Office of Energy Efficiency - OEE plays the crucial role. It is responsible for implementations of a state-owned mission: "Leading Canadians to Energy Efficiency at Home, at Work and on 
the Road" (OEE 1998). In practice, the OEE is responsible for promoting information, establishing regulations, implementing solutions, and the coordination of funding systems associated with energy, energy efficiency and the use of renewable energy sources. The federal strategy is followed by strategies of cities and provinces.

Vancouver, the city on the west coast of Canada, was recognised as the most interesting example. Distinct actions, aimed at the realization of sustainability in practice, are visible in its contemporary development. The first manifestations of the sustainable development of Vancouver turned up in 1994, when the City Development Plan was being created. In the urban part of planning, it was projected among others to convert post-industrial areas into a sustainable community (Punter 2003).

First efforts of implementing sustainability into operation were not simple, as the contemporary boss of the Department of Planning claimed (in 1998). Only a few years later, in 2009, the Greenest City Action Plan (GCAP) came into existence. It was supposed to lead Vancouver to achieve the name of 'The Greenest City in the Word' (City of Vancouver 2012).

This initial set of goals and targets was drawn up by the group of 14 experts in ecology and economics. It stipulated specific 75 quick-start operations that the staff of the City of Vancouver could begin to act on immediately. As a result, in 2011 the Greenest City 2020 Action Plan was accepted. More than 35 thousand people from around the world participated in the process online, through social media and in face-to-face workshops or events. More than 9.5 thousand people living in Vancouver actively added their ideas and feedback to achieve this plan. Over 60 people of the City staff and more than 120 organisations contributed to the creation of the GCAP (GCAP, p. 6). This plan has accompanied all undertakings in the city. Its message is "to create opportunities today while building a strong local economy, vibrant and inclusive neighbourhoods and an internationally recognized city that meets the needs of generations to come" (GCAP, p. 6). It is often emphasized that the achievement of these objectives has not been easy, particularly because it refers to changes of beliefs and habits which for years have been practised by clerks. Now they are brought to the new light.

The aims of the GCAP are concentrated on three essential issues: clean energy, waste and ecosystems. The plan is divided into mutually interweaving scopes, which are to be carried out in two stages: the medium-term until 2020 and the long-term until 2050. These scopes are at the same time ten essential areas which cause the city to be the greenest in the world. These are: Green Economy, Climate Leadership, Green Buildings, Green Transportation, Zero Waste, and Access to Nature, Lighter Footprint, Clean Water, Clean Air, and Local Food. One of conclusions made during working over the plan was that the City needs to set an example in its own operation. It is one of the keys to achieve the social favour and approval. Four high-priority actions in City operations have been identified in response. 1) Plan and implement a comprehensive corporate waste reduction and diversion for all City facilities. 2) Develop a procurement policy and practice that supports the purchase and use local food in City-run facilities, including community centres and Park Board restaurants and concessions. 3) Look for opportunities to green community events that the City runs, sponsors and permits. 4) Plan and implement a programme to significantly reduce greenhouse gas emissions as well as fossil fuel use in City-run buildings and vehicles, and achieve carbon-neutral operations. These actions are supposed to be model and demonstrate operations for City dwellers.

A detailed description of all areas of the GCAP influence is not a purpose of this work. Four issues, amongst the mentioned above, are especially interesting though.

Firstly - the Green Buildings (GCAP p. 22-25). Still, before the implementation of the plan, Vancouver had the most demanding legislation referring to the energy efficiency of buildings in North America. Already since 2006, all the newly built objects in the city had to fulfil energy standards stricter than legal obligations from the Statute of Canada (MNEC 2010).

This means that their power consumption must be about $20 \%$ and $37 \%$ lower, appropriately for multi-apartment buildings and for industrial, commercial and institutional buildings (Energy Savings Plan 2007). In spite of this fact, the GCAP considers these issues as the need for education of developers and owners of buildings. The purpose is to build consciousness of the impact of buildings on the environment and to initiate considering energy efficiency as a higher value than the straight income on sales of energy-gobbling apartments.

Moreover, since 2010 all newly constructed buildings in Vancouver must meet high requirements of green building. They must meet the LEED Gold standard (Leadership in Energy and Environmental Design). One example is the Olympic village from 2010 located on False Creek, where two basic green solutions were successfully applied (Fig. 2). One is connected with the reduction of energy consumption achieved by responsible façades in a form of diverse sun protective screens, which generate savings in the cooling of buildings in summer. The other one is related to the reduction of potable water consumption, where captured rainwater is used for irrigation of greenery and constitutes a landscape element of the development. The Olympic Village was designed as a part of the revitalization programme of post-industrial areas. It is regarded as one of the most sustainable neighbourhoods in the world which received the LEED Platinum (Bayley 2009).

Secondly - the Green Transportation (GCAP p. 28-33). The city makes efforts to pursue the goal of over $50 \%$ of 

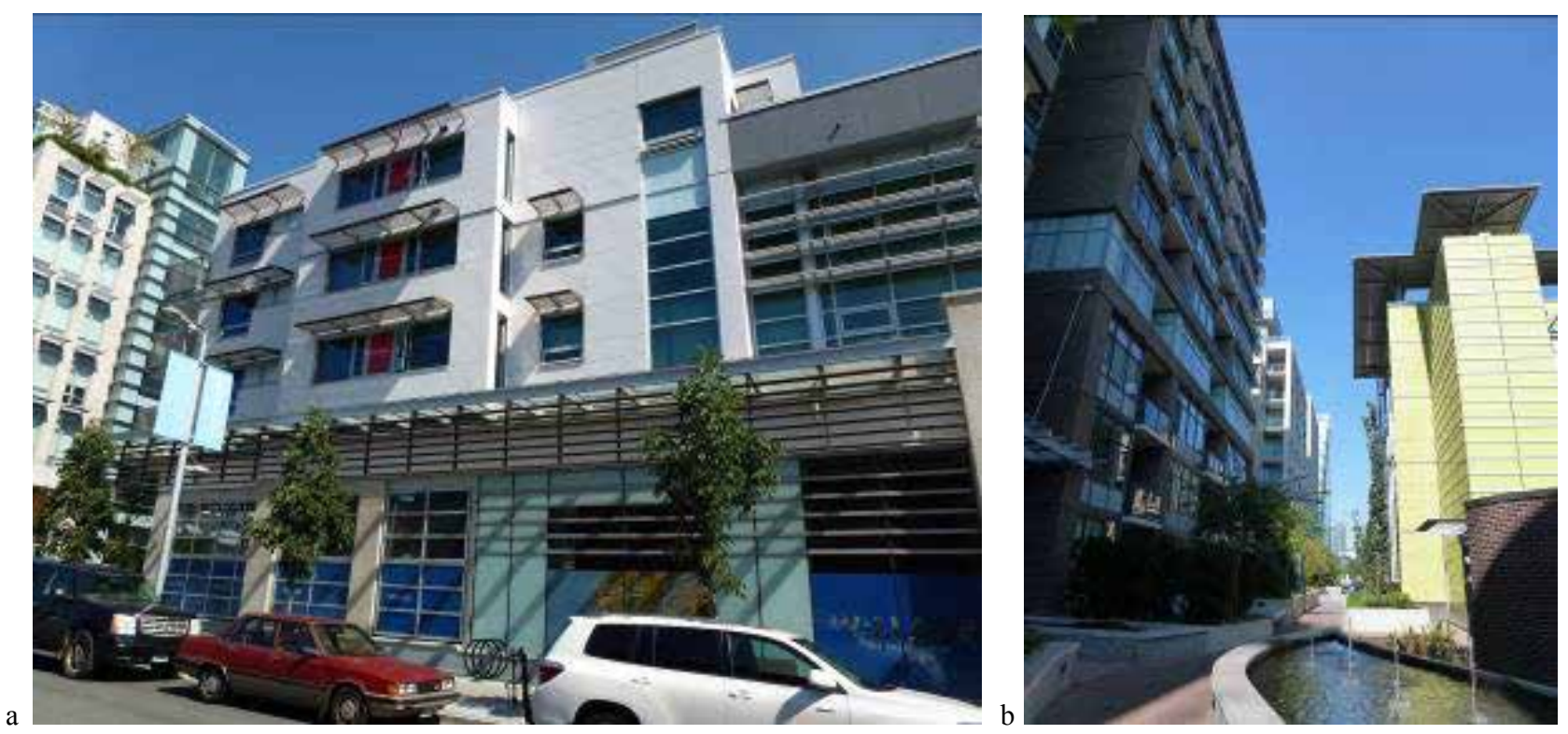

Figure 2. False Creek Development - The Olympic Village: a) diverse sun protective screens, b) rain catchers on the roof

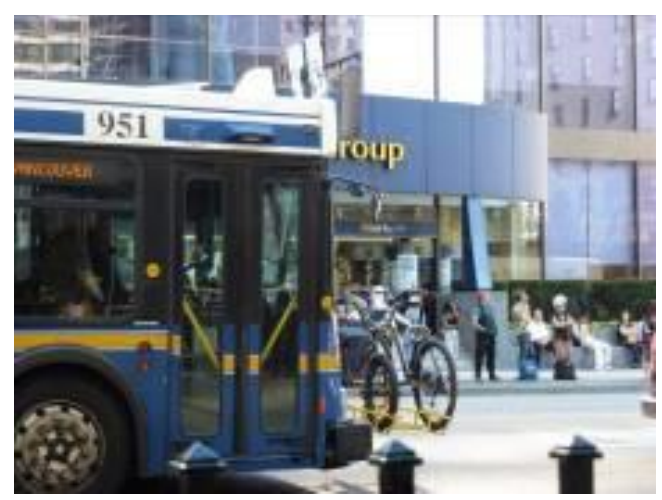

a
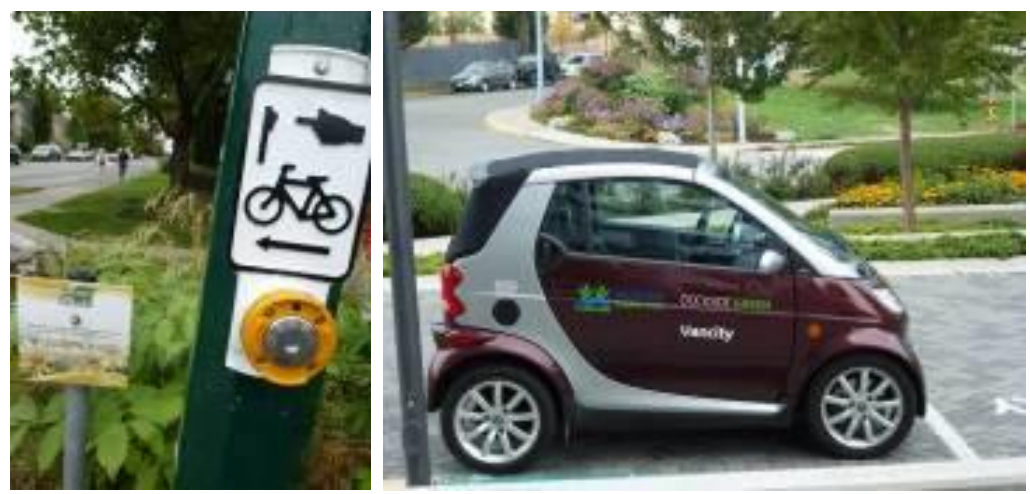

b

Figure 3. Green Transportation: a) very good infrastructure for bicycle, b) car powered by photovoltaic panels

communication in the city to occur on foot, on a bike or by means of mass transportation. The concern for health and well-being of the citizens, as well as the quality of air in the city, are indicated in this issue. Streets, public walks and neighbourhoods should be vibrant places that are alive with people, plants and activities. The availability of living, work and play in a 5-minute walking distance is one of the elements of sustainable planning of the city (Farr 2008; Condon 2010). Thus, Vancouver has at its disposal a very good infrastructure of bicycle and public transportation. In accordance to the GCAP, the City creates conditions for pedestrians and cyclists to feel safe, convenient, comfortable, and fun for all ages and abilities. Obtaining Green Transportation is connected, i.a. to providing the secure and comfortable infrastructure for bicycles. For long - distance trips, transporting bicycle on a rack in front of a municipal bus is possible. On street crossings, bicycles have the same privileges as pedestrians. Cars using renewable energy sources and car-share systems also become popular. There are firms hiring cars in a car-share system, which work on electricity derived from photovoltaic panels (Fig. 3).

Thirdly - Waste Zero (GCAP p. 34-39). This part of the programme is supposed to encourage lowering the level of rubbish intended for recycling. Therefore, it encourages to 'three Rs' which means: recycling, reducing and reusing as priority. Achievement of Zero Waste level is connected to a competent waste disposal. In practice, it means a consistent selective collection of rubbish in such a way that the smallest amount remains for recycling. It results in the presence of many containers for different purpose (Fig. 4).

This strategy helps to avoid the extraction of raw resources and conserves the energy used to produce new products. Actions include i.a. grants for sharing co-ops 

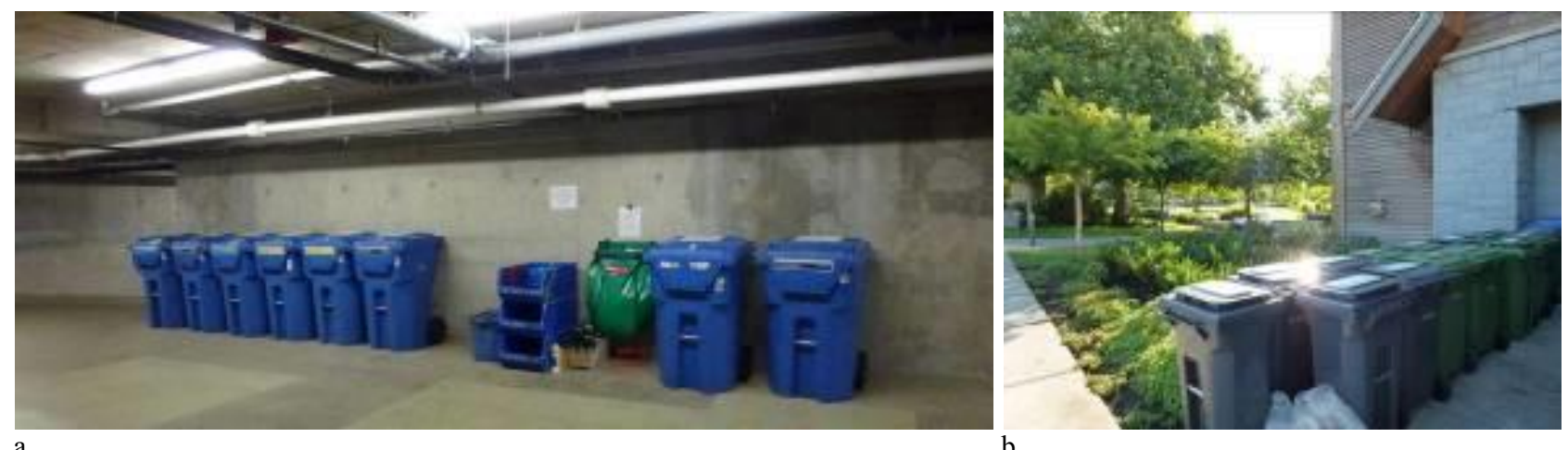

Figure 4. New standard view of various containers: a) in a garage of a residential tower in Yaletown, b) outside public buildings at the University of British Columbia

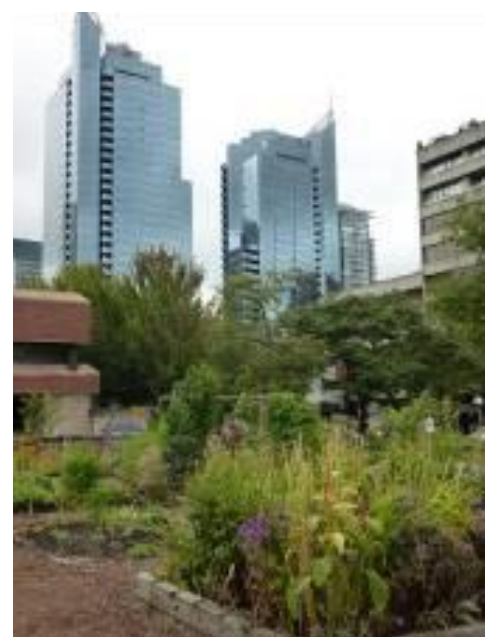

a

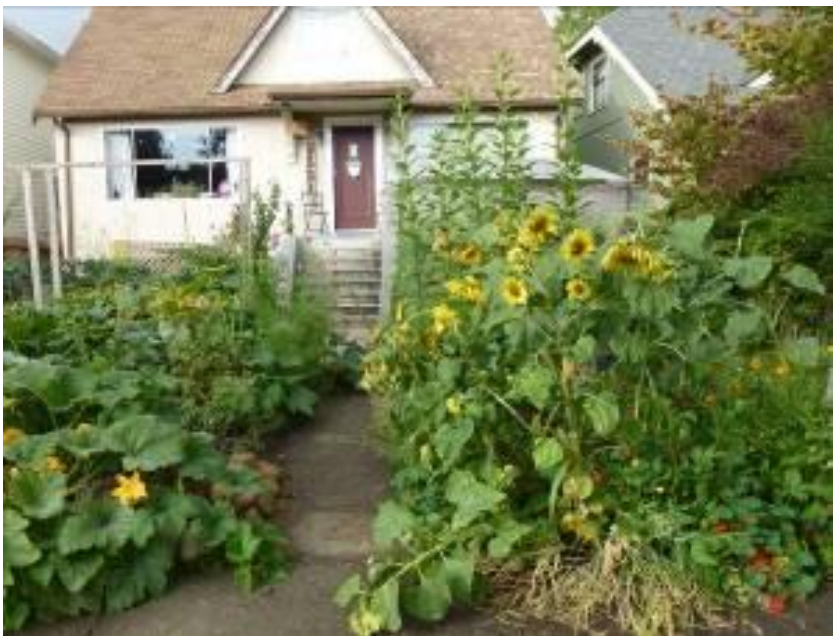

b

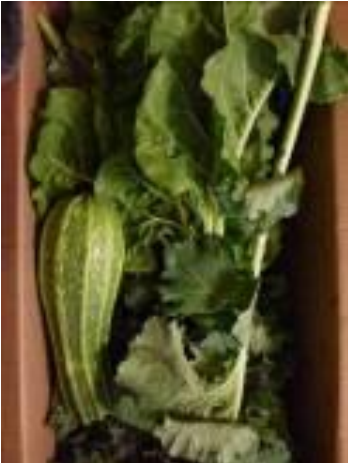

Figure 5. Local food production: a) community garden located in the city centre surrounded by public buildings, b) private garden used as an urban farm in exchange for veggie-boxes and lending libraries for things like tools, toys and vehicles. One also popularizes a cradle-to-cradle design among producers that is a design in which an entire life cycle of a product is taken into consideration (McDonough \& Braungart 2002). A very important point is that the waste created through the construction of new buildings or the demolition of old ones is recycled in $76 \%$. Moreover, food scraps, compostable paper, yard trimmings, and other organic waste make up about a third of Vancouver waste stream. That is why composting from single-family households, piloting a collection programme from apartments and condominiums, and ensuring compostables also from business and institutions, are strongly promoted.

Finally fourthly - Local Food (GCAP p. 64-69). It means that the distance from farm to plate is as short as possible. But it also includes factors such as working conditions of people who grow and harvest the food, the nonuse of pesticides and the affordability or accessibility of food for all residents. In such understanding, the food asset includes among others community kitchen, farmers market, community products' stand, community for composting facilities, community garden plots or urban orchards and urban farms. Local Food assurance involves the creating of community gardens which are located in various places in the City, e.g. in school areas, near parks and squares. A specific community takes care of a garden. There also exist urban farms. Their activity consists in opening a private garden to growing vegetables and flowers, and in exchange in obtaining a so-called veggie box from gained yields. Such gardens are grown by small companies which are looking after a few gardens in the area (Fig. 5).

The majority of the GCAP assumptions is not new to the city. It is emphasized though that its comprehensive implementation requires employing all the citizens. 

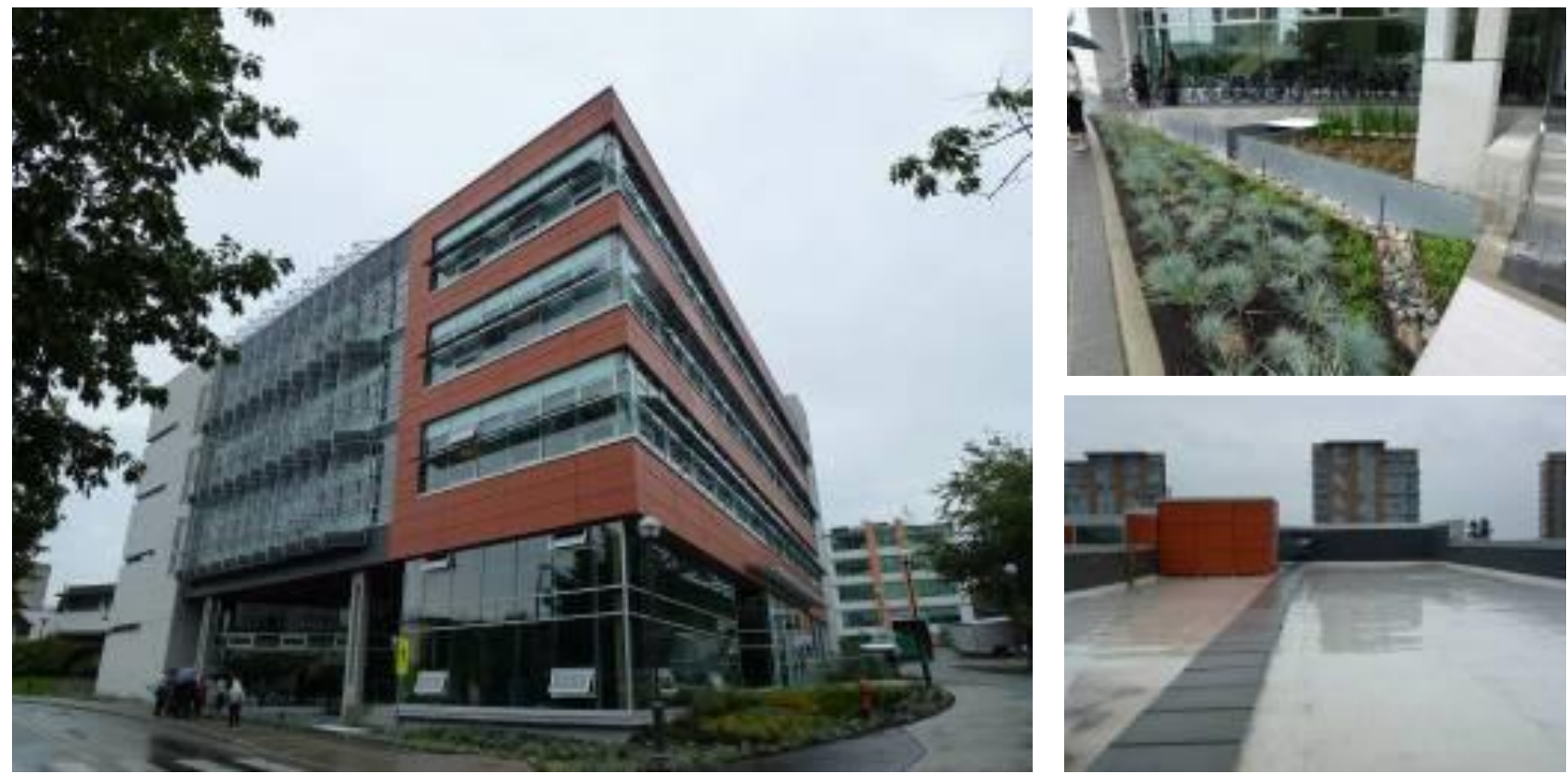

$\mathrm{b}$

Figure 6. CIRS at the UBC: a) building, b) rainwater distribution around the building and rainwater collecting on the roof

\section{Notable effects}

The measurable effects are one of the GCAP major accomplishments, because the majority of goals and targets refer to the improvement of a state that was previously defined. For example, one of deliberate aims in the area of Local Food refers to the amount of farmers markets. The GCAP records that in Vancouver there were 4 farmers markets in 2009, whereas 22 are planned to function till 2020 (GCAP p. 66). In the area of Access to Nature it is projected to create four to six new mini-parks by converting right-of-way streets into parks (GCAP p. 42). It is also determined that the implementation of plan into force would contribute to the creation of almost 15,000 new places of employment (GCAP p. 12).

The fact that Vancouver takes the first place in the ranking of "The 2011 Most Sustainable Cities in Canada" is the notable effect of all drawn above action, starting from the City Development Plan from 1998 to this day (Marchington 2011). Vancouver reached it in the category of average cities, i.e. from 250,000 to 700,000 citizens. In this ranking, cities were ranked according to 28 indicators across five categories: social well-being, ecological integrity, governance and empowerment, infrastructure and the built environment, and economic security. Each category is a determinant for the living city in which sustainable communities are formed.

Institutions, organizations, workplaces, schools, and universities follow the drawn action taken by the City. The biggest in the City, the University of British Columbia -
UBC merits attention. The Sustainability Centre, the UBC Sustainability Initiative, as well as a building -living laboratory - the Centre for Interactive Research on Sustainability - CIRS, were established (Fig. 6).

The Centre for Interactive Research on Sustainability building - CIRS, at the UBC, put into operation in 2012. There is a Net Zero Energy thanks to exploiting the warmth being waste from mechanical ventilation of the neighbouring building. Moreover, it produces electricity for own purposes using photovoltaic panels being sun protective screens at the same time. The building is also water self-sufficient, among others thanks to the storage of rainwater from the roof inlaid with white foil and the biofiltration of black water situated on the ground floor. Purified water is reused in toilets and for irrigation. CIRS is a sample of green solutions' application in an educational building (Bać 2013).

The big increase of interest in sustainability is proved by the fact that in 2007 only three Canadian universities took part in "College Sustainability Report Card" that ranks a 100 leading universities in North America on their campus environment and how they invest their endowments (Peterson 2007). While, as the research of the Author demonstrates, in 2012 all of the leading Canadian universities refer to issues of sustainability, not only into campus operations but also in sustainable courses and other actions and events.

To sum up, apart from respected legislation and policy actions, the community is the greatest power and at the same time - the limitation. Therefore, in Vancouver all the action is managed and directed towards it (Maxwell 2006). 


\section{Recapitulation}

Materials demonstrated constitute an example of realization of the concept of sustainable development. They present a course of the process to achieving sustainability. It takes time and array of deliberate action to reach sustainability. To achieve sustainability of cities, one should give, above all, practical rather than only a paper rank of the Sustainable Development Strategy. Authorities of towns and urban planners should get acquainted with leading world examples of sustainable cities and use their achievements and lessons learned. One should direct politics of the state, as well as local politics in accordance to the principles of sustainability. Local governments should set examples in such action.

The issue of sustainability should be constantly repeated or even become a media uproar, if this is the way to reach social awareness. One should create indicators, helpful in achieving the TBL. Legislation should follow political actions, which similarly to the strategy, will not remain only on paper. In reaching sustainability, the action of education is helpful, especially on the university level. One should implement the TBL in centres of higher education, so that the idea and issues of sustainability become present in mass social awareness. All that determines the key to success. Materials presented can become a model for implementing sustainability in Polish cities, what requires conducting subsequent examination.

\section{Acknowledgments}

The review presented in this paper is a part of the research grant by the Ministry of Science and Higher Education in years 2010-2012 as a research project No. N N527 159638.

\section{References}

Bać A., 2013, Laboratorium zrównoważenia - modelowy budynek uniwersytecki w Vancouver [Laboratory of sustainability - model university building in Vancouver], Architectus 2 (34/2013): 83-92.

Bader P., 2008, Sustainability: Conceptual Approaches. From Principle To Practice, Goethe Institut, http:// www.goethe.de/ges/umw/dos/nac/den/en3106180.htm [Accessed 2.04.2011].

Baranowski A., 1998, Projektowanie zrównoważone w architekturze [Sustainable design in architecture], Wydawnictwo Naukowe Politechniki Gdańskiej, Gdańsk.

Bayley R., 2009, The Challenge Series, http://www. thechallengeseries.ca/ [Accessed 14.06.2012].

CAGBC - Canada Green Building Council, 2012, LEED Canada for Neighbourhood Development, http://www.
cagbc.org/AM/PDF/nd\%20outline\%20092209\%20 Eng.pdf [Accessed 10.04.2012].

Carson R., 1962, Silent Spring, Houghton Mifflin Co., Boston.

City of Vancouver, 2012, Greenest City 2020 Action Plan, http://vancouver.ca/files/cov/Greenest-city-action-plan. pdf [Accessed 18.04.2012].

Condon P., 2010, Seven Rules for Sustainable Communities. Design Strategies for the Post Carbon World, IslandPress.

Ellington J., 1994, Towards the Sustainable Corporation: Win-Win-Win Business Strategies for Sustainable Development, California Management Review 36 (2/1994): 90-100.

Energy Savings Plan, 2007, http://www.saveenergynow.ca/ vancouver [Accessed 8.02.2012].

Farr D., 2008, Sustainable Urbanism. Urban design with nature, John Wiley\&Sons, New Jersey.

Gibson R., 2006, Sustainability assessment: basic components of a practical approach, Impact Assessment and Project Appraisal 3, 2006, Taylor\&Francis, London, http://www.tandfonline.com/ doi/pdf/10.3152/147154606781765147 [Accessed 22.10.2013].

Global Footprint Network, 2012, August 22 was Earth Overshoot Day, http://www.footprintnetwork.org/en/ index.php/GFN/page/earth_overshoot_day/ [Accessed 13.04.2012].

Hartig G. L., 1795, Anweisung zur Taxation der Forste, oder zur Bestimmung des Holzer: trags der Wälder, after Weimann H. J., 2003, Wurzeln der Nachhaltigkeit. LWF aktuell 37: 34-37.

King A. \& Schneider B., 1993, The First Global Revolution, Club of Rome.

Marchington E., 2011, The 2011 Most Sustainable Cities in Canada, http://www.corporate knights.com/report/2011-most-sustainable-cities-canada/methodology [Accessed 14.03.2011].

Maxwell J., 2006, Looking Down the Road: Leadership for Canada's Changing Communities, Canadian Policy Research Network for Community Foundations of Canada, http://www.leadershipwaterlooregion.org/ user_files/images/File/LookingDownTheRoad(2).pdf [Accessed 12.01.2012].

McDonough W. \& Braungart M., 2002, Cradle to cradle. Remaking the Way We Make Things, North Point Press, New York.

Meadows D., Meadows D., Randers J., 2004, Limits to Growth: The 30-Year Update, Chelsea Green Publishing Company, White River Jct., Vermont.

Model National Energy Code of Canada for Houses, 2010, National Model Construction Code Documents, http:// www.nationalcodes.nrc.gc.ca/eng/nech/index.shtml [Accessed 9.11.2011]. 
Natural Resources Canada, 2008, New Federal Sustainable Development Strategy, http://www.nrcan.gc.ca/sustainable-development/federal-context/2386 [Accessed 18.11.2011].

Office of Energy Efficiency, 1998, Our Vision, http://oee. nrcan.gc.ca/corporate/17024 [Accessed 13.11.2011].

Paszkowski Z., 2011, Miasto idealne w perspektywie europejskiej i jego związki z urbanistyką współczesną [Ideal City in the European perspective and its connections to the modern urban planning], Wyd. Universitas, Kraków.

Peterson G., 2007, Ranking University Sustainability, http://rs.resalliance.org/2007/01/29/ranking-university-sustainability/ [Accessed 8.4.2011].

Punter J., 2003, The Vancouver Achievement Urban Planning and Design, UBC Press. http://vancouver.ca/ green-vancouver/greenest-city-2020-action-plan.aspx [Accessed 18.04.2012].

Slaper T. \& Hall T., 2011, The Triple Bottom Line: What Is It and How Does It Work?, Indiana Business Review, Spring 2011, 86(1), http://www.ibrc.indiana.edu/ ibr/2011/spring/article2.html [Accessed 27.03.2012].

Suzuki D., 2007, Foreword, P. Busby: Learning Sustainable Design, Perkins+Will, Janam Publications Inc. Gatineau: 2-7.

The Greenest City Action Team, Vancouver 2020. A Bright Green Future, 2009, https://vancouver.ca/files/cov/ bright-green-future.pdf [Accessed 3.04.2011].
Von Carlowitz H. C., 1713, Reprint 2000, Sylvicultura oeconomica, Bergakademie, Freiberg. http://www. waldwissen.net/lernen/forstgeschichte/lwf_wurzel_nachhaltigkeit/index_DE [Accessed 9.02.2012].

United Nations, 1987, Our Common Future. Report of the World Commission on Envoronment and Development, http://conspect.nl/pdf/Our_Common_Future-Brundtland_Report_1987.pdf [Accessed 12.03.2011].

United Nations, 1992, Agenda 21, The United Nations Programme of Action From Rio, http://www.un.org/esa/ dsd/agenda21/ [Accessed 3.04.2011].

Wehle-Strzelecka S. \& Korczyńska A., 2007, Ochrona środowiska w kształtowaniu współczesnej przestrzeni miejskiej $\mathrm{w}$ aspekcie idei ekologii miasta [Environmental protection in the shaping of contemporary urban space from the point of view of urban ecology approach], A-Czasopismo Techniczne, Wydawnictwo Politechniki Krakowskiej, http://suw.biblos.pk.edu.pl/ resources/i5/i3/i9/r539/WehleStrzeleckaS_OchronaSrodowiska.pdf [Accessed 9.02.2012].

Zabłocki G., 2002, Rozwój zrównoważony: Idee, Efekty, Kontrowersje [Sustainable Development: Ideas, Effects, Controversies], Wydawnictwo Uniwersytetu Mikołaja Kopernika, Torun.

Zimny H., 2005, Ekologia miasta [Urban ecology], Agencja Reklamowo-Wydawnicza A. Grzegorczyk, Warszawa. 